\title{
Hana Červinková (red.): Antropologia i edukacja. Etnograficzne badania edukacyjne w tradycji amerykańskiej. Wrocław 2019, Wydawnictwo Naukowe Dolnośląskiej Szkoły Wyższej, ss. 407
}

Rok 2019 w Polsce to czas wprowadzania w życie następnej reformy kształcenia nauczycieli w ramach studiów wyższych. Wiąże się ona z kolejnym już Rozporządzeniem Ministra Nauki i Szkolnictwa Wyższego w sprawie standardu kształcenia przygotowującego do wykonywania zawodu nauczyciela, w trzech zakresach: 1) nauczyciela przedmiotu, nauczyciela teoretycznych przedmiotów zawodowych, nauczyciela prowadzącego zajęcia i nauczyciela psychologa; 2) nauczyciela przedszkola i edukacji wczesnoszkolnej (klasy I-III szkoły podstawowej); 3) nauczyciela szkoły specjalnej i oddziału specjalnego oraz nauczyciela prowadzącego zajęcia z dziećmi i z uczniami ze specjalnymi potrzebami edukacyjnymi.

Nie jest moim celem zajmowanie się w tym miejscu analizą tego dokumentu, zwracam jednak uwagę na jego zapisy w kontekście postulatu Hany Červinkovéj, aby włączyć w znacznym wymiarze - wzorem Stanów Zjednoczonych Ameryki i wielu państw Unii Europejskiej - zajęcia z zakresu antropologii kulturowej do kształcenia nauczycieli. Już na wstępie zatem stwierdzam, że w projektowanej aktualnie reformie i wspomnianych wyżej standardach edukacji nauczycielskiej w Polsce treści z tego zakresu albo w ogóle nie przewidziano, albo przewidziano w minimalnym stopniu. Chodzi tu praktycznie wyłącznie o standardy kształcenia nauczycieli przedszkola i edukacji wczesnoszkolnej, w ramach których pojawiają się odniesienia do kultury, antropologicznych aspektów edukacji, społeczeństw wielokulturowych czy edukacji międzykulturowej. Wypada wobec tego żywić nadzieję, że zajęcia z szeroko rozumianej antropologii kultury i edukacji zostaną wprowadzone w ramach programów studiów wyższych na kierunkach i specjalnościach nauczycielskich jako rezultat odpowiedzialnych decyzji senatów poszczególnych szkół wyższych, o ile podzielać będą one argumenty Hany Červinkovéj przedstawione w rozdziale wprowadzającym do antologii przekładów zatytułowanej Antropologia i edukacja. Etnograficzne badania edukacyjne w tradycji amerykańskiej, wydanej na początku 2019 roku przez Wydawnictwo Naukowe Dolnośląskiej Szkoły Wyższej pod redakcją naukową tej wybitnej uczonej o międzynarodowej renomie. 
Dr hab. Hana Červinková, prof. DSW we Wrocławiu, jest antropolożką kultury, pedagożką, zaangażowaną badaczką kulturowych uwarunkowań procesów edukacyjnych, specjalistką w zakresie uczestniczących badań w działaniu, założycielką i dyrektorką Międzynarodowego Instytutu Studiów nad Kulturą i Edukacją w DSW oraz liderką projektu dydaktycznego European Doctorate in Teacher Education realizowanego w ramach programu UE Horyzont 2020. Pochodzi z Republiki Czeskiej, a do Polski przyjechała z Ameryki. Od wielu lat prowadzi rozbudowaną międzynarodową współpracę naukową w środowiskach antropologów kultury i edukacji oraz pedagogów i badaczy edukacji z różnych krajów. Zajmuje się też kształceniem nauczycieli. Recenzowany tom wpisuje się w wiedzę z zakresu antropologii kulturowej dla nauczycieli właśnie, bo jest bezpośrednią pochodną bogatych doświadczeń jego redaktorki w stosowaniu przez nią tekstów antropologicznych i badań etnograficznych w edukacji nauczycielskiej z bezpośrednim nawiązaniem do tradycji amerykańskiej. Teksty zamieszczone w tomie, w wersjach oryginalnych lub tłumaczonych na język polski, służyły bowiem efektywnie w kształtowaniu antropologicznych, kulturowych, metodologicznych, interpretacyjnych, międzykulturowych, emancypacyjnych itd. kompetencji studentów i studentek studiów nauczycielskich w ramach zajęć przez nią prowadzonych. Antologia ta jest zatem pomyślana przede wszystkim jako pomoc dydaktyczna w realizacji analogicznego kształcenia, jednak jej wartość naukowa, poznawcza, metodyczna i edukacyjna jest znacznie większa.

W tomie znalazło się łącznie 13 rozdziałów, których autorami są przede wszystkim - jak podkreśla redaktorka - przedstawiciele środowiska amerykańskiej antropologii edukacji skupionego wokół Council on Anthropology and Education działającej przy American Anthropological Association (m.in. George Spindler, Louise Spindler, Ray P. McDermott, Shirley Brice Heath, Bradley A. Levinson, Frederick Erickson, Thea Renda Abu El-Haj, Beth C. Rubin, Brian F. Hades, Pauline Lipman, Katherine Schultz, Kathryn Luet). Teksty te pierwotnie opublikowane zostały w różnych kontekstach czasowych (najwcześniej w 1974 roku, ale w większości po roku 2000), w renomowanych czasopismach albo uznanych monografiach naukowych w Stanach Zjednoczonych Ameryki i po raz pierwszy ukazują się w języku polskim. Dodać w tym miejscu należy, że w 2010 roku również w Wydawnictwie Naukowym DSW w ramach tej samej serii Biblioteki Współczesnej Myśli Społecznej ukazała się analogiczna antologia przekładów klasycznych tekstów antropologiczno-pedagogicznych zatytułowana Badania w dziataniu. Pedagogika i antropologia zaangażowane, pod redakcją naukową Hany 
Červinkovéj i Bogusławy Doroty Gołębniak. Tom ten odegrał istotną rolę w rozwoju tej tradycji badawczej w naukach społecznych w naszym kraju. Nie mam wątpliwości, że recenzowany tu zbiór również przyniesie analogiczne impulsy prorozwojowe w metodologii i praktyce etnograficznych badań edukacyjnych w Polsce oraz wykorzystaniu klasycznej i współczesnej wiedzy antropologicznej w edukacji nauczycieli. Poszczególne rozdziały dotyczą bowiem między innymi następujących tematów, zagadnień, kwestii: metodyki nauczania i uczenia się antropologii - rozumianej jako transkulturowe badania nad człowieczeństwem - w edukacji nauczycielskiej; transmisji kulturowej na podstawie studiów porównawczych ze szczególnym uwzględnieniem koncepcji kulturowej kompresji, ciągłości i nieciągłości; porównawczej antropoetnografii dwóch szkół w różnych kontekstach przestrzennych i temporalnych, z wyeksponowaniem kategorii terapii kulturowej; osiągania szkolnych niepowodzeń przez grupy pariaskie, czyli odrzucane przez populację dominującą, w aspekcie analfabetyzmu i stratyfikacji społecznej, w połączeniu z biobehawioralną etnografią trudności w czytaniu czy ekologią gier grup rówieśniczych; nauczycielek wczesnej edukacji jako badaczek etnograficznych uczenia się mowy przez małe dzieci; konstruowania tożsamości osoby wyedukowanej na przykładzie idiomów kultury meksykańskiej szkoły średniej; koncepcji kultury i stosowania analizy kulturowej w badaniach edukacyjnych; partycypacyjnej etnografii w działaniu realizowanej w ramach badań edukacyjnych, ze szczególnym uwzględnieniem „badań ręka w rękę”; wykorzystania zasobów wiedzy domostw latynoskich w edukacji szkolnej na podstawie badań etnograficznych prowadzonych przez nauczycieli; kształcenia do demokratycznego obywatelstwa w warunkach transnarodowych migracji i globalnych konfliktów społecznych na przykładzie młodych Palestyńczyków; edukacyjnego potencjału i metodologicznej złożoności obywatelskich badań w działaniu z młodzieżą z odniesieniem do problemu narkotyków w szkołach; konsekwencji polityki neoliberalnej władz metropolitalnych wobec edukacji publicznej, na przykładzie reformy szkolnictwa w Chicago; budowania i niszczenia zaufania relacyjnego w toku wdrażania reform oświatowych w USA z perspektywy ich skutków dla społeczności lokalnej.

Zbiór tekstów Antropologia i edukacja stanowi znakomite źródło inspiracji dla rozwoju pedagogiki polskiej w kilku kluczowych zakresach, a mianowicie: epistemologicznym, metodologicznym, dydaktycznym i krytyczno-emancypacyjnym.

W zakresie epistemologicznym recenzowana antologia tekstów to de facto monografia wieloautorska skomponowana intencjonalnie przez jej redak- 
torkę naukową, a wskazująca na - rzadko u nas uprawiany - typ studiów i badań interdyscyplinarnych lokujący się na styku antropologii kulturowej i pedagogiki (czy - jak by to określił Elliot W. Eisner - edukologii). W takim podejściu traktuje się szkołę jako instytucję kulturową, analizuje się kulturowe uwarunkowania procesów edukacyjnych, interpretuje się idiomy kultur etnicznych z perspektywy pedagogicznej, wielokulturowość traktuje się jako źródło inspiracji wychowawczych, a międzykulturowość - jako wyzwanie humanistyczne dla edukacji formalnej, pozaformalnej i nieformalnej, nauczycieli postrzega się jako animatorów zmiany prospołecznej, zjawiska i procesy wychowawcze rozumie się i wyjaśnia zawsze w relacji do kultury, poszukuje się obszarów marginalizacji i wykluczenia społecznego z przyczyn kulturowych oraz adekwatnych rozwiązań edukacyjnych w duchu zaangażowanej transformacji emancypacyjnej. Tak konstruowana wiedza antropologiczno-pedagogiczna wzbogaca wydatnie świadomość teoretyczną i praktyczną zarówno badaczy kultury, jak i edukacji, dostarczając opisów kultur edukacji w perspektywie porównawczej.

W zakresie metodologicznym książka ta promuje i wzbogaca metodologię etnograficznych badań edukacyjnych rozumianych jako jakościowe badania terenowe nad wychowaniem/edukacją, ze szczególnym uwzględnieniem paradygmatu partycypacyjnego i perspektywy krytyczno-emancypacyjnej nauk humanistyczno-społecznych. Etnografia należy do najstarszych, zaawansowanych tradycji badawczych w naukach humanistyczno-społecznych i wywodzi się z antropologii kulturowej zainteresowanej przede wszystkim kulturami etnicznymi świata. Jednak już dawno została poddana uniwersalizacji metodologicznej i z powodzeniem stosowana jest na całym świecie w badaniach pedagogicznych, najczęściej jako etnografia szkoły czy edukacji. Recenzowany tom dostarcza zarówno opisów konkretnych projektów badawczych zrealizowanych z zastosowaniem elementów etnografii, jak i przywołuje charakterystyczne podejścia, metody, techniki badań etnograficznych wykorzystane na gruncie amerykańskich antropologii edukacji, często $\mathrm{w}$ triangulacyjnym powiązaniu z pokrewnymi sposobami realizacji badań jakościowych. Osoby poszukujące rozwiązań dylematów związanych z projektowaniem własnych badań, zainteresowane edukacją i przekonane do orientacji jakościowych, znajdą wśród tych tekstów wiele cennych inspiracji metodologicznych.

W zakresie dydaktycznym antologię Antropologia i edukacja można traktować jako podręcznik do realizacji zajęć uniwersyteckich ze studentami kierunków nauczycielskich, w szczególności w zakresie antropologicznych podstaw edukacji oraz metodologii badań pedagogicznych. Taka zresztą 
była intencja redaktorki tomu, gdy podejmowała starania o jej przygotowanie i opublikowanie. Poszczególne teksty mogą być z powodzeniem traktowane jako lektury do krytycznego omawiania podczas konwersatoriów w celu poszerzania i pogłębiania świadomości oraz wrażliwości wielokulturowej i międzykulturowej przyszłych nauczycieli. W warunkach polskich, kiedy mamy do czynienia aktualnie z intensyfikacją procesów migracyjnych z Polski i do Polski, kompetencje takie są wręcz niezbędne w szkołach we wszystkich środowiskach, nie tylko na terenach pogranicza wieloetnicznego czy w miejscowościach zamieszkiwanych przez przedstawicieli mniejszości narodowych. Uczulanie na różnorodność kulturową, wpajanie postaw empatycznych wobec Inności, uczenie tolerancji i szacunku w odniesieniu do odmienności kulturowej, organizowanie bezpośredniego doświadczania wielokulturowości i jej edukacyjnego oddziaływania, odkrywanie na nowo własnej tożsamości kulturowej jako konstruktywnego efektu spotkania z dotychczasową Obcością to szczególnie aktualne wyzwania wszelkich procesów edukacyjnych, choć tylko w minimalnym zakresie uwzględniane jako cele kształcenia nauczycieli w naszym kraju. Recenzowana antologia ma szansę przełamania tego niekorzystnego i niezrozumiałego nastawienia zarówno projektodawców standardów edukacji nauczycielskiej, jak i jej realizatorów w konkretnych szkołach wyższych.

W zakresie krytyczno-emancypacyjnym tom ten konsekwentnie potwierdza program naukowy, jaki od lat realizuje w naszym kraju Hana Červinková, wykorzystując swoje amerykańskie doświadczenia. Stała się bowiem jedną z czołowych reprezentantek zaangażowanej antropologii i pedagogiki krytyczno-emancypacyjnej, co odzwierciedlają jej prace badawcze i publikacje naukowe. Tym razem po raz kolejny postarała się, aby dobór tekstów amerykańskich uczonych zajmujących się antropologią edukacji był wyraźnie nastawiony na promowanie pedagogii krytycznej, zaangażowanych badań uczestniczących, pedagogiki emancypacyjnej, projektowania transformującego. W szczególności bowiem uwagę czytelników postanowiła zwrócić w stronę grup marginalizowanych, mniejszościowych, defaworyzowanych, wykluczanych, opresjonowanych w różnych kontekstach kulturowo-edukacyjnych oraz na szanse i możliwości, bariery i pułapki, konkretne rozwiązania i ich rezultaty procesów dydaktycznych, wychowawczych, socjalizacyjnych z myślą o kreowaniu lepszego świata dla wszystkich ludzi niezależnie od różnic etnicznych, rasowych, klasowych czy innych. Tak pojmowane nastawienie w kształceniu nauczycieli wzmacnia dobitnie ich kompetencje krytyczne, zachęca do zaangażowania w zmiany prospołeczne i prohumanistyczne przez 
edukację oraz buduje ich tożsamość zawodową jako transformatywnych intelektualistów i aktywnych uczestników promowania idei demokratycznego obywatelstwa.

Zapewne każdy z czytelników odnajdzie w tej publikacji znacznie więcej walorów poznawczych i kształcących treści w odniesieniu do zagadnień szczegółowych dotyczących konkretnych problemów pedagogicznych, zjawisk edukacyjnych czy sytuacji wychowawczych, a także metodologicznych rozwiązań specyficznych elementów projektów badawczych wykorzystujących podejścia etnograficzne i szerzej jakościowe. Z pełnym przekonaniem rekomenduję ten tom jako cenny i odkrywczy zbiór opracowań mogący wielorako inspirować zaangażowanych badaczy edukacji oraz przyszłych i obecnych nauczycieli o inklinacjach antropologiczno-pedagogicznych.

Dariusz Kubinowski 